| Review / Derleme |

\title{
The Turkish National Remedial Program (TNRP) to Combat the Negative Effects of the Covid-19 Pandemic
}

\section{Covid-19 Salgınının Olumsuz Etkileriyle Mücadelede Türkiye Ulusal Destekleme Programı (TUDEP)}

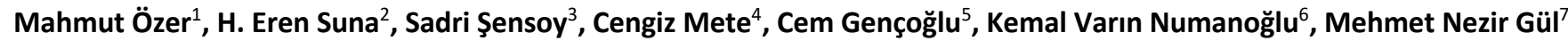

Keywords

1.covid-19

2.remedial education

3.academic support

4.learning loss

5.educational equity

Anahtar Kelimeler

1.covid-19

2.destek eğitimi

3.akademik destek

4.öğrenme kaybı

5.eğitimde eşitlik

Received/Başvuru Tarihi 22.03.2021

Accepted / Kabul Tarihi 03.05.2021

\begin{abstract}
The Covid-19 pandemic has led unique negative consequences in education. Due to the closure of schools, educational services have been carried out through distance education in many countries. Physical restrictions and staying away from the schools have negative consequences both on the physiological and psychological attributes of the students. Therefore, international institutions such as United Nations Educational, Scientific and Cultural Organization (UNESCO) and Organisation for Economic Co-operation and Development (OECD) advise countries to reopen schools as soon as possible and implement remedial programs. Due to the school closures, all educational services have been provided by distance education for nearly a year in Turkey. After the reopening of schools as of March 2021, Ministry of National Education (MoNE) has initiated Turkish National Remedial Program (TNRP) to support the students' academic skills as a two-stage program. The first phase of the project is designed as an emergency action plan, and the students in regions with the lowest participation in distance education were prioritized. The second phase of the project is designed as a large-scale support program that will cover all students and will be implemented during the summer months. The purpose of this study is to evaluate the second stage of TNRP by taking into consideration the international criteria for remedial programs and best practices around the world. The document analysis method is used to evaluate the second stage of TNRP. It is concluded that the second phase of TNRP is in coherence with international standards in terms of targeting all students from primary school to the end of secondary education, providing academic support with compressed content with critical outcomes, assessing the level of student achievement, prioritizing students who need special education, and making flexible programming to maximize participation.

Öz

Covid-19 salgını, eğitim alanında büyük olumsuzluklara yol açmıştır. Salgına bağlı olarak okulların kapanması nedeniyle birçok ülkede eğitim faaliyetleri uzaktan eğitimle gerçekleştirilmiştir. Uzun süre evde kalmak ve okulun sunduğu imkânlardan yararlanamamak öğrencilerin fizyolojik ve psikolojik özellikleri üzerinde çeşitli olumsuzluklar doğurmaktadır. Bu nedenle Birleşmiş Milletler Eğitim, Bilim ve Kültür Örgütü,(UNESCO) ve Ekonomik Kalkınma ve İşbirliği Örgütü (OECD) gibi uluslararas kurumlar, okulların en kısa sürede tekrar açılması ve akademik destek programlarının uygulanması konusunda ülkelere çağrıda bulunmaktadır. Türkiye'de de salgına bağlı olarak okullar yaklaşık bir yıl kapalı kalmış, bu dönemde tüm eğitim faaliyetleri uzaktan eğitim ile sağlanmıştır. 2021 yılının mart ayı itibarıyla okulların tekrar açılması ile Milli Eğitim Bakanlığı (MEB), öğrencilerin akademik becerilerini desteklemek için Türkiye Ulusal Destekleme Programını (TUDEP) başlatmıştır. İki aşamalı olan bu projenin ilk aşaması bir acil müdahale programı olarak planlanmış, uzaktan eğitime katılımın en düşük olduğu ilçelerdeki öğrenciler önceliklendirilmiştir. Projenin ikinci aşaması ise tüm öğrencileri kapsayacak ve yaz aylarında uygulanacak geniş ölçekli bir destek programı olarak tasarlanmıştır. Bu çalışmanın amacı, TUDEP'in ikinci aşamasını destek programlarının oluşturulmasında önerilen uluslararası ölçütler ve iyi uygulama örneklerini dikkate alarak değerlendirmektir. Çalışmada, TUDEP'in ikinci aşamasının değerlendirilmesi için doküman analizi yöntemi kullanılmıştır. TUDEP'in ikinci aşamasında ilkokuldan ortaöğretimin sonuna kadar tüm öğrencilerin hedeflenmesi, akademik desteğin önceliklendirilen alanlarda ve kritik kazanımlarla verilmesi, program hedeflerine ulaşma düzeyinin değerlendirilmesi, özel eğitime ihtiyaç duyan öğrencileri önceliklendirmesi ve katılımı en yüksek düzeye taşıyacak şekilde esnek bir programlama yapılması yönleriyle uluslararası standartlarla uyumlu olduğu sonucuna varılmıştır.
\end{abstract}

\footnotetext{
${ }^{1}$ Milli Eğitim Bakanlığı, Ankara, TURKEY; https://orcid.org/0000-0001-8722-8670

${ }^{2}$ Corresponded Author, Milli Eğitim Bakanlığı, Ankara, TURKEY; https://orcid.org/0000-0002-6874-7472

${ }^{3}$ Milli Eğitim Bakanlığı, Ölçme Değerlendirme ve Sınav Hizmetleri Genel Müdürlüğü, Ankara, TURKEY; https://orcid.org/0000-0002-2430-7520

${ }^{4}$ Milli Eğitim Bakanlığı, Ortaöğretim Genel Müdürlüğü, Ankara, TURKEY; https://orcid.org/0000-0001-6177-1093

${ }^{5}$ Milli Eğitim Bakanlığı, Temel Eğitim Genel Müdürlüğü, Ankara, TURKEY; https://orcid.org/0000-0003-2589-8673

${ }^{6}$ Milli Eğitim Bakanlığı, Mesleki ve Teknik Eğitim Genel Müdürlüğü, Ankara, TURKEY; https://orcid.org/0000-0001-7344-9157

${ }^{7}$ Milli Eğitim Bakanlığı, Özel Eğitim ve Rehberlik Hizmetleri Genel Müdürlüğü, Ankara, TURKEY; https://orcid.org/0000-0002-9911-7553
}

Citation/Alıntı: Surname, N., Özer, M., Suna, H. E., Şensoy, S., Mete, C., Gençoğlu, C., Numanoğlu, K. V., \& Gül, M. N. (2021). The Turkish National Remedial Program (TNRP) to Combat the Negative Effects of the Covid-19 Pandemic, Kastamonu Education Journal, 29(2), 442-451. doi: 10.24106/kefdergi.91367 


\section{INTRODUCTION}

The Covid-19 pandemic has precipitated unique and negative effects in global education (OECD, 2020a, 2020b). More than 1.6 billion students across the world were removed from school at some point during the pandemic period (Brossard et al., 2020; UNICEF, 2020a). In other words, Covid-19 and its attendant social distancing measures have pushed more than $90 \%$ of the world's student population out of educational institutions (Micks \& Mcllwaine, 2020). Countries have gone to great lengths to create alternative methods of maintaining student learning outside of school and designed these interventions relatively quickly due to the speed of the pandemic's spread (Gouedard et al., 2020; Özer et al., 2020).

Educational delivery methods vary greatly between countries (Carvalho \& Hares, 2020). In countries that were already wellprepared for distance education, the transition to virtual learning was quicker and lower-effort. Countries such as America and Canada, which have long histories of distance education and robust infrastructures for such methods, made preparations to maintain students' learning at the primary and secondary levels through remote instruction and e-learning (Carvalho \& Hares, 2020; Özer \& Suna, 2020). On the other hand, the pandemic precipitated educational problems in many African countries, which had already faced significant educational access issues for many years (Carvalho \& Hares, 2020). In these countries, lessons are typically provided through printed books, as well as through limited radio and television programming, since only a certain part of the population has access to such devices (UN Education Agency, 2020). Therefore, national infrastructure and socioeconomic status has dictated the country's preparedness for remote instruction over the course of the pandemic.

Although educational processes vary from region to region, it was inevitable that the distance education provided during Covid19 would differ greatly from the face-to-face education typically offered in schools (UNESCO et al., 2020; UNESCO, 2020b). Schools are environments where students interact with their peers and teachers; they are designed to ensure students' multidimensional development, beyond solely academic growth. Therefore, school closures curtail the benefits of many other opportunities offered by the school environment aside from teaching and learning (Özer et al., 2020). Since homes became students' main educational environment during the pandemic period, the impact of home resources on student learning became more pronounced (Brossard et al., 2020; Maldonado \& De Witte, 2020; Özer et al., 2020; Pershad et al., 2020). For this reason, researchers have considered the effects of the pandemic on students from a broad perspective (UNESCO et al., 2020, 2021). Consequently, numerous studies have focused on the economic and social consequences of learning losses during this time (Dorn et al., 2020; Maldonado \& De Witte, 2020; Psacharapoulos, 2020; World Bank, 2020b).

Students' learning processes have experienced visible impacts due to the pandemic. The pause in conventional classroombased education due to the pandemic has led to deficiencies in students' academic skills (Daniel, 2020; Kaffenberger, 2020; Kuhfeld \& Tarasawa, 2020; Maldonado \& De Witte, 2020; Özer \& Suna, 2020; UNICEF, 2020a). Studies show that learning losses, resulting from deficits in these skills, have a significant impact on student development (OECD, 2020a, 2020b; Suna \& Özer, 2020). Because education is a cumulative process, such learning losses can also hinder students' future learning (Kaffenberger, 2020). Based on this fact, UNICEF and UNESCO have called the countries to take all actions possible to make classrooms as safe as possible and reopen the schools (UNESCO, 2020c; UNICEF, 2020c). Learning losses influence educational investments, too. Studies have indicated that five months of school closure can cause countries can lose up to $16 \%$ of their education investments (UNESCO, 2020a). Therefore, as countries currently prepare to reopen schools, they are also establishing remedial programs to alleviate these learning losses.

With the Covid-19 pandemic under at least partial control in most of the world, many countries have begun reopening schools and resuming conventional classroom-based education (Gouedard et al., 2020; The World Bank, 2020; UNICEF, 2020a). However, students' learning losses can pose critical obstacles during this transition (UNICEF, 2020a; United Nations, 2020). Thus, many countries have initiated various remedial programs to compensate for these learning losses (UNESCO, 2020a). The structure of these programs varies between countries, depending on the length of school closure, the educational delivery mode(s) utilized during the pandemic period, and the structure and elements of the educational system.

International organizations focusing on education and its strong links with economic development have strongly emphasized the need to support students due to the disproportionate impact they faced as a result of the pandemic (UNICEF, 2020a; UNESCO, 2020; United Nations, 2020; World Bank, 2020). Such organizations consider remedial programs an urgent need, due to the psychological and physiological repercussions of the pandemic on students (Gouedard et al., 2020; Kaffenberger, 2020; United Nations, 2020; UNESCO, 2020a). Researchers have emphasized the importance of support programs at this critical moment, explaining that "if in normal times, a lack of focus on implementation may result in no change, in times of Covid-19, the lack of a coherent education response strategy by a country can result in failure to continue student learning." (Gouedard et al., 2020, p.7).

Modeling studies, which take into account the experiences of previous school closures, show that support programs are the most important measure for reducing the negative effects of the pandemic (Das et al., 2020). In addition, the fact that the impact of the pandemic has lasted longer than many previous disasters necessitates changes in the structure of academic support programs. Modeling studies show that if an intensive remedial program is implemented and its curricula are reorganized according to the specific deficiencies the program seeks to address, learning losses will decrease significantly in the long term (Kaffenberger, 2020).Additionally, remedial programs are effective interventions for narrowing the achievement gaps between student groups (Chen \& Yu, 2016; Guitterez \& Rodrigo, 2014). In this manner, these programs are also important for coping with the achievement gap between students in Covid-19 pandemic. 
The educational services at all levels in Turkey have been maintained through distance education (mainly on the Education and Information Network [EBA]) for nearly a full year (Özer, 2020a, 2020b; 2020c). Material support for students, including the necessary equipment for remote instruction, continued throughout the year to increase access to distance education. However, academic support is also necessary to compensate for the year of school interaction that students have missed out on due to social distancing. The importance of program is also critical for narrowing the achievement gap between schools in Turkey (Bölükbaş ve Gür, 2020; Karaağaç Cingöz ve Gür, 2020; Suna, Tanberkan \& Özer, 2020; Suna et al., 2020a; 2020b; Suna ve Özer, 2021a; 2021b). To meet this need, the Turkish Ministry of National Education (MoNE) initiated the Turkish National Remedial Program (TNRP) with the reopening of schools in March 2021. Structured as a two-phase project, the TNRP prioritizes students in the regions with the lowest access to distance education in its first phase. Thus, this first stage is designed to focus on the most disadvantaged student groups as an emergency remedial program. In the second phase, beginning in the summer months, the scope of academic support will be expanded for all students in a large-scale remedial program covering all levels of schooling, from the beginning of primary education to the end of secondary education. This program has been designed as an overarching umbrella that includes the other support programs implemented before the pandemic. The aim of this study is to evaluate the structure of the second stage of the TNRP program comparatively with international criteria and examples. The study provides the detailed planning of TNRP for the first time and it focuses the coherence between the global best practices and planning of MoNE. Within this scope, the present study is important for evaluating the approach of MoNE in designing the remedial program based on the global criteria.

\section{Method}

The document analysis method is used to evaluate the second stage of TNRP based on the international criteria and best practices. The document analysis is a qualitative method which includes depth review of related documents including the papers, books, and reports (Bowen, 2009; Creswell, 2014). In this manner, the literature about the remedial programs is reviewed and reports of international institutions on education and economy are emphasized. Additionally, the best practices and models from diverse countries to cope with negative effects of Covid-19 pandemic are considered. The best practices around the world and suggestions of international organizations are discussed in related titles.

\section{Principles of Remedial Programs and Best Practices around the World}

In every education system, there are always students who have difficulty achieving educational outcomes for various reasons. Lack of support may lead these students to be unsuccessful in the long term and to withdraw from their educational goals (Johnston, 2010; Wilson et al., 2011). Therefore, remedial programs make an important contribution to closing these inequalities in education, as they prioritize supporting students who cannot meet the required benchmarks due to various disadvantages.

Remedial programs are designed around a common purpose, but their structure and schedule differ from one country to another (Abraham, 2019; UNESCO, 2020a). Countries can create specific support programs by grouping students according to their competencies, providing one-to-one education by increasing the number of teachers, or maintain a common remedial education without grouping, facilitating collaborative and group-based activities to mitigate differences between students (Abraham, 2019; Schwartz, 2012). The main reason for these differences is that each education system has unique characteristics and elements.

While remedial programs have become a priority in the Covid-19 pandemic period, many questions have arisen about how to realize this priority. The multidimensional and unique nature of the impact of the pandemic in each country necessitates different national solutions (Gouedard et al., 2020; UNESCO, 2020a). International organizations such as the World Bank, OECD, and UNESCO have stated that the best solution will be country-specific, just like the problem itself (UNESCO, 2020a). However, various international criteria should also be considered to increase the quality of the remedial programs offered.

Based on the multidimensional impact of the pandemic on students, UNESCO has proposed a four-stage approach for the development of a qualified remedial program (UNESCO, 2020a). The first stage (envisioning and understanding) involves understanding the current situation and problem areas. At this stage, educators should determine the distribution of learning losses and establish a clear academic plan. In the second stage (decide and design), the timeframe and format of the support program is designed. During this stage, educators answer questions such as how, with which tools, and for what amount of time academic support will be offered to students, based on the structure of the education system. The third stage (enable and execute) considers allocating the necessary budget to implement the program, as well as organizational planning. This stage also includes the coordination of human resources and the preparation of the targeted curriculum. In the last stage (monitor and adjust), the effectiveness of the support program is determined through measurement and evaluation methods. This final stage involves various methods for evaluating the extent to which the program compensates for learning losses. Designing the support program in a way that considers these four stages is essential for the creation of an inclusive and highly accountable remedial program.

To minimize the negative impact of the pandemic, many countries are implementing remedial programs following the fourstage approach recommended by UNESCO (UNESCO, 2020a). In the United States, the state of Maryland increased school hours to minimize learning losses, added weekend and night classes, and reinforced support through summer school programming. The state of New York also implemented summer school to compensate for students' learning losses due to the pandemic. Italy has decided to hire more than 24,000 new teachers to implement a remedial program before starting the new academic semester. $A$ volunteer teaching program was initiated to compensate for students' learning losses in England by calling on retired teachers to volunteer. Belgium has announced a free summer camp for all students; schools there can elect to open for summer camps, and 
have additional budget allocated for this programming. France and Ontario (Canada) have narrowed their curriculum for use in their remedial programs. After the beginning of the semester in France, Saturday classes were organized until the summer months, and summer schools and summer camps were announced, where all students can participate. In addition, the French government has proposed to extend the official academic calendar to cover the summer months.

\section{The Turkish National Remedial Program (TNRP): The Second Stage}

\section{Target Group}

The pandemic has kept students home from school for quite a while, causing disruption to students' daily routines that negatively affects their lives (UNESCO, 2020a; 2020b). Although research had indicated that some disadvantaged student groups have suffered greater losses due to these changes, the duration of the pandemic and its restrictions have affected all student populations. For this reason, it is important to provide support to all students regardless of their competencies and socioeconomic status. As emphasized by Kaffenberg (2020) and the World Bank (2020c), the second stage of the TNRP has been designed as a large-scale remedial program that will include all students. The goal of reaching all students is also an important step in the context of equality in education. This objective is associated with many current support programs carried out for disadvantaged students in Turkey, such as IYEP, DYK, and the 1000 Schools in Vocational Education Project (Gençoğlu, 2019; Özer, 2021; Özer et al., 2020).

\section{Time of Implementation}

Depending on the reopening date of schools in wake of the Covid-19 pandemic, remedial programs may extend over a long period of time. Many countries established additional teaching hours to support students after schools reopened. In addition, some countries have structured remedial programs in the summer period to increase and permanently establish this level of support. Studies have also shown that the implementation of such summer programs positively contributes to academic and social skills (McCombs et al., 2011; Potter, 2020).

TNRP is designed as a two-stage program, to match this approach. The first stage of TNRP, conceived as an emergency response plan, begins in March; while the second stage, which is completely focused on academic support, is scheduled to commence in July and August. In addition, the 1000 Schools in Vocational Education Project, IYEP, and DYK have been added within the scope of TNRP.

The second TNRP stage planned for July and August aims to realize a remedial project focused entirely on learning losses after the school year, which is currently in its second term. The scheduling of the TNRP for the summer months allows the processes planned for the academic year to be completed without any delay, to produce more support materials, and to plan for the realization of this large-scale project simultaneously.

\section{Disciplines Covered in the Remedial Program}

Remedial programs generally prioritize main disciplines such as mathematics, reading, and science (Simonez, 2016). These programs aim to upskill students in the disciplines prioritized by the educational system, rather than offering a basic repetition of the training provided during the semester. It is easier for students who gain these skills to acquire other skills in diverse disciplines within the scope of the course (Schwartz, 2012).

The TNRP aims to support and develop students' skills in three main disciplines: Turkish language, mathematics, and science. Thus, the project includes, Turkish language, mathematics, and science courses in primary education; and Turkish Language and Literature, mathematics, physics, chemistry, and biology courses in secondary education.

Students' mathematics, science, and Turkish language skills are considered as their main resources for solving problems encountered in daily life, as well as the foundation of knowledge to support the development of skills in other areas. For this reason, the TNRP prioritized supporting students' skills in these disciplines. Although the remedial program is structured around these three disciplines, many support materials and activities have been developed for other subject areas as well.

This project will determine critical outcomes in mathematics, Turkish language, and science at both the primary and secondary education level. These critical outcomes that facilitate access to other educational objectives will be decided for each grade level. After the determination of these outcomes, the education process for the project, which will last approximately two months, will be structured in order to reach them. The identified outcomes will also determine which training materials will be used and which tools will be developed to assess student learning.

\section{Assessment of Support for Students}

Measurement and evaluation methods have been used for different purposes in remedial programs during the pandemic period, including determining the status of students' learning and how compatible the support education is with student needs (UNESCO, 2020a). The types of measurement and evaluation methods implemented within the scope of these programs also differ between countries. In countries such as France, the remedial program begins with direct assessment, while some other countries use indirect assessments such as teacher feedback and previous student data (UNESCO, 2020a).

While direct assessment provides more information about students' learning, it can also lead to test-taking anxiety for students. While such anxiety is mitigated through using indirect assessment in lieu of direct examinations, the information 
obtained is more limited. In the beginning of the second stage of the TNRP, indirect assessment is preferred to minimize the testtaking anxiety for students, who have been out of school for nearly a year. For this purpose, the remedial program will be planned around data from national monitoring studies, scores from central examinations, and teacher feedback.

During the TNRP's second stage, two large-scale assessments will be conducted to assess students' Turkish language, mathematics, and science skills. The first of these evaluations will be performed at the end of July, one month after the start of the program, while the other will occur at the end of August, immediately following the program's completion. The results of both assessments will provide important feedback on the program and students' performance of critical outcomes. The assessments will be developed and implemented by the General Directorate of Measurement, Assessment, and Examination Services (ÖDSHGM).

\section{Flexibility in Program Participation}

The benefits of remedial programs are maximized when as many students participate in them as possible (Kaffenberger, 2020; World Bank, 2020c). As previously stated, the second stage of the TNRP is designed for all students from the beginning of primary education to the end of secondary education. Therefore, a flexible plan has been built to encourage students from all grade levels to attend the program. In addition to the advantages of the implementation in the summer months, the increase in the mobility of students, parents, and teachers during these months is also a factor to be taken into account.

In order to maximize the participation of students in the second step of the TNRP program, administrators will ensure that students can participate in any province. Since the program will be conducted in July and August, students who will be in different provinces for various reasons (parents' jobs, vacation travel, etc.) will be able to participate in the program no matter their location. Similarly, teachers participating in the program will also have the chance to work in whichever province they are located. Thus, this plan aims to increase participation in the program and maximize the program's contribution, while taking into account the personal preferences of students, parents, and teachers.

\section{Academic Supports for Diverse Education Levels}

The TNRP has been designed as an overarching umbrella that will include the support programs currently implemented by the MoNE. Therefore, the support and training courses (DYK) implemented since the 2014-2015 academic year, the Remedial Education \& Support Programme in Primary Education (IYEP) implemented since the 2018-2019 academic year, the 1,000 Schools in Vocational Education Project launched in the 2020-2021 academic year are also included in the TNRP.

\section{a. Supports at the Basic Education Level}

In order to support students at the basic education level, the critical outcomes in Turkish language, mathematics, and science will be determined from 1st through 4th grade at the primary school level, and classroom teachers will provide education on these outcomes for two months. Due to the structure of the Turkish national curricula, the focus will be on students' Turkish language and mathematics skills in 1st-4th grade, and science skills in 3rd and 4th grade.

Before the TNRP begins in the summer months, the IYEP program, which was implemented in the 2018-2019 academic year, will assess the needs of primary school students and begin addressing those needs. Within the scope of the IYEP, educators will determine whether the students at the 3rd grade level have reached the expected outcomes; the students who are not at a sufficient level will participate in IYEP. The MoNE is currently seeking to increase the number of participants in IYEP, which reached more than 300,000 students during the 2018-2019 academic year. This program will focus on students' mathematics and Turkish skills, while science skills will be improved with additional resources in the summer.

The General Directorate of Primary Education (TEGM) has carried out many studies during the pandemic to support the academic skills that the remedial program will focus on. This office has developed set of 17 workbooks on Turkish language, mathematics, science, and life sciences for students studying in unified classrooms in rural areas. Worksheets named "Tohum" ("Seed") have been developed for 1st grade students who learning to read. For 3rd and 4th grade students, activities supporting Turkish language development named "Topaç" ("Top") were developed. For the social, emotional, and language development of primary school students, the "Reading Fish Audio Electronic Library" has been established. "I am Ready to Learn" workbooks have been prepared for Turkish language and mathematics at all grade levels in primary school. The ÖDSHGM also developed pamphlets for 4th grade students in Turkish language, mathematics, science, English, social studies, religion, and ethics. Lastly, the ÖDSHGM completed a new project designed to evaluate the reading skills of 4th grade students and provide them with appropriate support materials.

At the secondary school level, critical outcomes in Turkish language, mathematics, physics, chemistry, and biology will be determined at all levels between the 5th-8th grade. Teachers will provide educational support in July and August for students to reach the outcomes in these disciplines. The DYK program, which has been implemented at the secondary school level since the 2014-2015 academic year, has been restructured within the scope of the TNRP.

The TEGM has developed many additional resources to be used in the remedial program and continues to work on this issue. This division developed 16 books on Turkish language, mathematics, science, social studies, and the Turkish Republic Revolution History and Kemalism for students in secondary schools. In addition, the TEGM employs 1,000 teachers in 50 provinces to develop 
workbooks in 118 fields and digital content in 58 fields. A total of seven books and audio files have been developed to improve students' foreign language skills from 2 nd-8th grade. The ÖDSHGM conducted an e-monitoring study to assess and improve 8 th grade students' science and mathematics literacy and reading skills. An extension of this study including students in 5 th-7th grade is also ongoing.

\section{b. Supports at the Secondary Education Level}

The DYK constitutes the main source of academic support for students at the secondary level. By making the necessary arrangements in the regulation of the DYK, the MoNE has opened remedial programs at different class levels in extraordinary situations such as a pandemic. The TNRP will also provide academic support in Turkish language and literature, mathematics, physics, chemistry, and biology at this level.

Another program included in the scope of the TNRP that provides academic support at the secondary education level is the 1,000 Schools in Vocational Education Project (Özer, 2021). This project administers multidimensional support to approximately 600,000 students in the 1,000 most disadvantaged vocational high schools, determined by criteria such as absenteeism rates, low school achievement, and disciplinary problems. This support covers the fundamental academic skills and social skills of students, training for teachers and parents, and school infrastructure. Using the resources allocated for this large-scale project within the scope of the TNRP will prioritize disadvantaged students who are more likely to be impacted by the negative effects of the pandemic. This project will provide support to all grade levels in vocational high schools, as all students in the selected schools are included.

The General Directorate of Secondary Education (OGM) has also developed diverse resources to support students during the pandemic. This office developed skill-based activities for various disciplines, including Turkish language and literature, mathematics, and science. During the pandemic, the OGM designed 2,247 skill-based activities at the 9th grade level and 980 activities at the 10th grade level. Similarly, skill-based activity development continues for the students in 11 th and 12 th grades. Moreover, 350 educational activities were developed in nine disciplines to support the students' learning after they resumed faceto-face education.

The OGM is still working on printing and distributing all the resources developed for EBA TV during the epidemic. Approximately 25,000 questions presented to students at the secondary education level were collected in a mobile question bank and provided to students to access offline from their mobile devices. The OGM also will extend the support offered to students in the 9th -11th grades who will take the University Examination (YKS).

The ÖDSHGM completed an e-monitoring study to assess 9th and 10th grade students' ability to apply their knowledge and skills in daily life. In this context, the assessment tool used to evaluate the students' high-level cognitive skills was also included in the remedial program.

\section{c. Supports for Students Who Need Special Education}

Disadvantaged student groups may be more affected by the negativities caused by extraordinary circumstances, like pandemics, natural disasters, and political unrest (Özer \& Suna, 2020; UNICEF, 2020b). Students who need special education may not benefit to the same extent from the opportunities designed for other students, as they have specific academic needs. As a result, these students may become more vulnerable in times of crisis and may be more affected by learning losses. Therefore, it is important to encourage and prioritize the participation of these students in remedial education programs.

The MoNE also included students who need special education within the scope of the project and prioritized the participation of these students to support their academic skills. It is predicted that 7,086 students from the special-education schools with general education programs will attend the program. The activities will be held by opening non-formal education courses through public education centers and providing support to the students in institutions with a special education curriculum. It is predicted that 33,548 students can benefit from the programs designed in this way.

Additionally, the TNRP will provide psychosocial support by considering the psychological negativities caused by students' lack of interaction with teachers and peers during quarantine and social distancing. School counselors in the program will develop programs to provide psychological support to students. Psychosocial helpline services established during the Covid-19 pandemic will continue within the scope of the TNRP as well. Thus, students, teachers, and families will be able to contact experts over the phone for psychosocial support.

The steps and schedule for the implementation of the second phase of the TNRP are given in Table 1.

Table 1. Estimated Schedule: Second Phase of TNRP

\begin{tabular}{|c|c|}
\hline Step & Date \\
\hline Determining of critical outcomes in Turkish language, mathematics and science & $1^{\text {st }}$ March-15th March 2021 \\
\hline Receiving feedback to critical outcomes in Turkish language, mathematics and science & $16^{\text {th }}$ March-31 ${ }^{\text {st }}$ March 2021 \\
\hline Structuring the education programs & $1^{\text {st }}$ April-31 $1^{\text {st }}$ April 2021 \\
\hline Receiving feedback to education programs & $1^{\text {st }}$ May-15 $15^{\text {th }}$ May 2021 \\
\hline Developing/adapting the assessment tools for education programs & $15^{\text {th }}$ May-31'st May 2021 \\
\hline
\end{tabular}




\begin{tabular}{ll}
\hline Step & Date \\
\hline Applications for students who enroll the program & $1^{\text {st } J u n e-18^{\text {th }} J u n e} 2021$ \\
Course Period & $1^{\text {st July-31 }}{ }^{\text {st }}$ August 2021 \\
First large-scale assessment & $25^{\text {th }}$ July-3 $3^{\text {rd }}$ August 2021 \\
Second large-scale assessment & $1^{\text {st }}$ Sptember-8 \\
\hline
\end{tabular}

As seen in Table 1, the steps for implementing the TNRP were initiated following the reopening of schools in March. The training programs and materials will be completed by July, when the implementation of the second phase of TNRP will start. The support program will be completed in the first week of September, when the second assessment will take place.

\section{DISCUSSION AND CONCLUSION}

The negative consequences of the Covid-19 pandemic have become more visible with the reopening of schools. Since the second half of 2020, countries begun reopening schools and the number of students receiving face-to-face education has increased. Early studies empirically illustrate the negative toll that time away from school has had on students' physical and psychological skills (Karasawa, 2020; Kuhfeld \& Tarasawa, 2020; Kuhfeld et al., 2020).

The most effective tools to compensate for the negative effects of the pandemic are remedial education programs. For this reason, international organizations such as the OECD, World Bank, and UNESCO advise all countries to implement remedial programs against learning losses (Gouedard et al., 2020; UNESCO, 2020a). Modeling studies show that learning losses from the pandemic can correspond to an education period of half a year to over a full year (Azevedo et al., 2020; Dorn et al., 2020; Kuhfeld \& Tarasawa, 2020; Kuhfeld et al., 2020). Moreover, the rates of learning loss for disadvantaged students, especially those from low socioeconomic backgrounds, may be even higher (Dorn et al., 2020). These findings clearly show the urgency and importance of remedial programs.

In Turkey, schools remained closed for almost a year; thus, the MoNE has planned a two-phase remedial program to compensate for students' learning losses. As of March 2021, when schools reopened nationally, the first phase of TNRP was initiated for the students in the regions with the lowest participation in distance education. Therefore, the first phase of the TNRP constitutes an emergency intervention during the semester for the most disadvantaged students. The second phase will reach all students from basic education to the end of secondary education levels during the summer months. This second phase aims to expand the scope of academic support to all students, in order to alleviate the effects of the pandemic before the 2021-2022 academic year. The present study reviewed the second phase of the TNRP based on the international criteria for remedial programs.

The differences in the impact of the pandemic from one country to another, as well as the distinct features in national education structures push countries to find their own solutions to this pressing issue of learning loss. However, there is a consensus on the steps to be taken to structure an effective academic support program (UNESCO, 2020a). The first of these steps is defined as envisioning and understanding the current situation and problem areas. In order to better discern students' learning losses in the second phase of TNRP, the outputs of the first phase and the results of the central examinations will be used together with teacher feedback. Thus, the data collected throughout the educational process will play a role in structuring the program, without creating additional test-taking anxiety for the students.

The second stage involves deciding and designing, and emphasizes three elements: increasing the time allocated to education, giving special importance to the program, and presenting the program with targeted content. These elements are reflected in the TNRP through implementation of the second phase in the summer months and the inclusion of previous support projects from before the pandemic within the scope of the TNRP. In addition, the critical outcomes in Turkish language, mathematics, and science are prioritized in this second phase.

The third stage (enable and execute) includes the allocation of financial and human resources for the support program, alongside the preparation of curriculum and education materials. The budget and human resources required for the TNRP have been arranged within the scope of previous support projects, especially the DYK. The process of creating a targeted curriculum and developing the educational materials is ongoing. Providing the opportunity for students and teachers to participate in the project from different provinces is important for maximizing access to the educational programming.

The last step of the process (monitor and adjust), includes the continuous assessment of the program and the evaluation of the implementation according to the monitoring results. Large-scale assessment will be performed in the first month and at the end of the program in order to determine the impact of the second phase of the TNRP and to assess the students' progress. During this process, feedback will be solicited from teachers and monitoring results will be shared with the public through reports published by the MoNE.

As a result, the second stage of TNRP has been established as an inclusive, flexible, and dynamic remedial program. The program structure and approach matches the UNESCO (2020a) recommendations which are covered in envisioning and understanding, deciding and designing, enable and execute, and monitor and adjust. 


\section{Declaration of Conflicting Interests}

The authors declared no potential conflicts of interest with respect to the research, authorship, and/or publication of this article.

\section{Funding}

The authors received no financial support for the research, author-ship, and/or publication of this article.

\section{Statements of publication ethics}

We hereby declare that the study has not unethical issues and that research and publication ethics have been observed carefully.

\section{Researchers' contribution rate}

The study was conducted and reported with equal collaboration of the researchers.

\section{REFERENCES}

Abraham, B. (2019). Effective strategies in remedial education. Journal for Research Scholars and Professionals of English Language Teaching, 15(39).

Azevedo, J. P., Hasan, A., Goldemberg, D., Iqbal, S. A., \& Geven, K. (2020). Simulating the potential impacts of COVID-19 school closures on schooling and learning outcomes. World Bank Group Policy Research Working Paper 9284. Retrieved from https://openknowledge.worldbank.org/bitstream/handle/10986/33945/Simulating-the-Potential-Impacts-of-COVID-19-School-Closures-onSchooling-and-Learning-Outcomes-A-Set-of-Global-Estimates. pdf?sequence=1\&isAllowed=y

Bowen, G. (2009). Document analysis as a qualitative research method. Qualitative Research Journal, 9(2), 27-40.

Bölükbaş, S., \& Gür, B. S. (2020). Tracking and inequality: The results from Turkey. International Journal of Educational Development, 78 , https://doi.org/10.1016/j.ijedudev.2020.102262.

Brossard, M., Cardoso, M., Kamei, A., Mishra, S., Mizunoya, S., \& Reuge, N. (2020). Parental engagement in children's learning. UNICEF Office of Research - Innocenti. Retrieved from https://www.unicefirc.org/publications/pdf/IRB\%202020-09\%20CL.pdf

Carvalho, S., \& Hares, S. (2020). More from our database on school closures: New education policies may be increasing educational inequality. Center for Global Development. Retrieved from https://www.cgdev.org/blog/more-our-database-school-closures-new-education-policies-maybe-in-creasing-educational

Chen, H.L., \& Yu, P. (2016). Closing achievement gaps and beyond: Teachers' reactions to the remedial education policy in Taiwan. Asia Pacific Education Review, 17(4), 609-624.

Creswell, J. W. (2014). Research design: Qualitative, quantitative and mixed methods approaches (4th ed.). London: SAGE Publication Inc.

Daniel, J. (2020). Education and the COVID19 pandemic. Prospects, doi: 10.1007/s11125-020-09464-3.

Das, J., Daniels, B. \& Andrabi, T. (2020). We have to protect the kids. RISE Insight Note No. 2020/016. RISE Programme. Retrieved from https://doi.org/10.35489/BSGRISE-RI 2020/016

Dorn, E., Hancock, B., Sarakatsannis,J., \& Viruleg, E. (2020). COVID-19 and student learning in the United States: The hurt could last a lifetime. McKinsey \& Company Public Sector Practice. Retrieved from https://www.mckinsey.com/ /media/McKinsey/Industries/ Public\%20and\%20Social\%20Sector/Our\%20Insights/COVID-19\%20and\%20student\%20learning\%20in\%20the\%20United\%20States\%20The\%20 hurt\%20could\%20last\%20a\%20lifetime/COVID-19-and-student-learning-in-the-United-States-FINAL.pdf 881.

Gençoğlu, C. (2019). Milli bir destekleme ve yetiştirme sistemi modeli: illkokullarda Yetiştirme Programı (iYEP), Milli Eğitim Dergisi, 48(1), 853-

Gouedard, P., Pont, B., \& Viennet, R. (2020). Education responses to Covid-19: Implementing a way forward. OECD Education Working Papers No. 224. Retrieved from https://www.oecd-ilibrary.org/docserver/8e95f977-en.pdf?expires=1615331335\&id=id\&accname=guest\&checksum= F40988931C8DD7D5B05C1A2AF3B7893B

Johnston, J. H. (2010). Dropout prevention: A research brief. Fairfield, CT: Education Partnerships, Inc.

Gutiérrez, E., \& Rodrigo, R. (2014). Closing the achievement gap in mathematics: evidence from a remedial program in Mexico City. Lat Am Econ Rev, 23, 14.

Kaffenberger, M. (2020). Modeling the long-run learning impact of the Covid-19 learning shock: Actions to (more than) mitigate loss. Retrieved from https://riseprogramme.org/publications/modeling-long-run-learning-impact-covid-19-learning-shock-actions-more-mitigate$\underline{\text { loss }}$

Karaağaç Cingöz, Z., \& Gür, B. S. (2020). Ekonomik, sosyal ve kültürel statünün akademik başarıya etkisi PISA 2015 ve TEOG 2017 sonuçlarının karşılaştırması. Insan ve Toplum, 10(4), 247-288.

Kuhfeld, M., \& Tarasawa, B. (2020). The COVID-19 slide: What summer learning loss can tell us about the potential impact of school closures on student academic achievement. Retrieved from https://www.nwea.org/blog/2020/covid-19-school-closures-couldhave-devastating-impactstudent-achievement/

Kuhfeld, M., Soland, J., Tarasawa, B., Johnson, A., Ruzek,E., \& Liu, J. (2020). Projecting the potential impacts of COVID-19 school closures on academic achievement. EdWorkingPaper No. 20-226.

Maldonado, J. E., \& De Witte, K. (2020). The effect of school closures on standardised student test outcomes. KU Leuven Discussion Paper Series 20.17. Retrieved from https://lirias.kuleuven.be/3189074?limo $=0$ 
Mccombs, J. S., Augustine, C. H., Schwartz, H. L., Bodilly, S.J., Brian. M., Lichter, D. S., \& Cross, A. B. (2011). Making summer count: How summer programs can boost children's learning. Santa Monica: RAND Corporation.

Micks, J., \& Mcllwaine, J. (2020). Keeping the world's children learning through COVID-19. UNICEF. Retrieved from https://www.unicef.org/coronavirus/keeping-worlds-children-learning-through-covid-19

OECD (2020a). A framework to guide an education response to the COVID-19 pandemic of 2020. Paris: OECD Publishing.

OECD (2020b). Education responses to COVID-19: Embracing digital learning and online collaboration. OECD Policy Responses to Coronavirus (COVID-19).

Özer, M., \& Suna, H. E. (2020). Covid-19 pandemic and education. In Şeker, M., Özer, A., \& Korkut, C. (Eds). Reflections on the pandemic: In the future of the world (pp. 159-178). Ankara: TÜBA.

Özer, M., Suna, H. E., Çelik, Z., \& Aşkar, P. (2020). Covid-19 salgını dolayısıyla okulların kapanmasının eğitimde eşitsizlikler üzerine etkisi. Insan ve Toplum, 10(4), 217-246.

Özer, M. (2020a). Educational policy actions by the Ministry of National Education in the times of COVID-19 pandemic in Turkey. Kastamonu Education Journal, 28(3), 1124-1129.

Özer, M. (2020b). The contribution of the strengthened capacity of vocational education and training system in turkey to the fight against COVID-19. Journal of Higher Education, 10(2), 134-140.

Özer, M. (2020c). Vocational education and training as "A friend in need" during coronavirus pandemic in Turkey. Bartın University Journal of Faculty of Education, 9(2), 1-7.

Özer, M., Gençoğlu, C., \& Suna, H. E. (2020). Türkiye'de eğitimde eşitsizlikleri azaltmak için uygulanan politikalar, OMÜ Eğitim Fakültesi Dergisi, 39(2), 294-312.

Özer, M. (2021). A new step towards narrowing the achievement gap in Turkey: "1,000 schools in vocational education and training" Project. Bartın University Journal of Faculty of Education, 10(1), 97-108.

Pershad, D., Comba, R., \& Bergmann, J. (2020). From schooling to learning for all: Reorienting curriculum and targeting instruction. Background paper, Averting an Education Catastrophe for the World's Children. Retrieved from https://saveourfuture.world/white-paper/

Potter, H. (2020). Expanding access to summer learning in response to COVID-19. Retrieved from https://tcf.org/content/report/expandingaccess-summer-learning-response-covid-19/?agreed=1.

Psacharopoulos, G., Patrinos, H., Collis, V., \& Vegas, E. (2020). The COVID 19 cost of school closures. Retrieved from https://www.brookings.edu/blog/educationplus-development/2020/04/29/the-covid-19-cost-of-school-closures/

The World Bank (2020a). Response to Covid-19 in Europe and Central Asia. Retrieved from http://pubdocs.worldbank.org/en/862141592835804882/ECA-Education-Response-Note-v9-final.pdf

UNESCO (2020a). COVID-19 response - remediation: Helping students catch up on lost learning, with a focus on closing equity gaps. Retrieved from https://www.mckinsey.com/ /media/McKinsey/About\%20Us/COVID\%20Response\%20Center/Overview/COVID-19\%20Education\%20 Response\%20Toolkit/202010 UNESCO-McKinsey\%20Response\%20Toolkit Remediation VF.pdf

UNESCO (2020b). Adverse consequences of school closures. Retrieved from

https://en.unesco.org/covid19/educationresponse/consequences

UNESCO (2020c). As a new academic year begins, UNESCO warns that only one third of students will return to school. Retrieved from https://en.unesco.org/news/new-academic-year-begins-unesco-warns-only-one-third-students-will-return-school

UNESCO, UNICEF, World Bank, World Food Programme, \& UNHR (2020). Framework for reopening schools.

UNESCO, UNICEF, World Bank, World Food Programme, \& UNHR (2021). Framework for reopening schools supplement: From reopening to recovery - Key resources. Retrieved from https://www.unicef.org/media/94741/file/Framework\%20for\%20Reopening\%20 Schools\%20Supplement-From\%20Reopening\%20to\%20Recovery-Key\%20Resources.pdf

UNICEF (2020a). COVID-19: Effects of school closures on foundational skills and promising practices for monitoring and mitigating learning loss. Retrieved from https://www.unicef-irc.org/publications/pdf/COVID-19 Effects of School Closures on Foundational Skills and _Promising_Practices_for_Monitoring_and_Mitigating_Learning_Loss.pdf

UNICEF (2020b). Covid-19: Are children able to continue learning during school closures? Retrieved from https://data.unicef.org/resources/remote-learning-reachability-factsheet/

UNICEF (2020c). COVID-19: UNICEF warns of continued damage to learning and well-being as number of children affected by school closures soars again. Retrieved from https://www.unicef.org/romania/press-releases/covid-19-unicef-warns-continued-damage-learning-and-wellbeing-number-children

United Nations (2020). Policy brief: Education during COVID-19 and beyond. Retrieved from https://unsdg.un.org/sites/default/files/202008/sg policy brief covid-19 and education august 2020.pdf

UN Education Agency (2020). Startling disparities in digital learning emerge as COVID-19 spreads. Retrieved from https://news.un.org/ en/story/2020/04/1062232

The World Bank (2020b). The World Bank's education response to Covid-19. Retrieved from http://pubdocs.worldbank.org/en/ $\underline{487971608326640355 / E x t e r n a l-W B-E D U-R e s p o n s e-t o-C O V I D-D e c 15 F I N A L . p d f}$

The World Bank (2020c). The Covid-19 pandemic: Shocks to education and policy responses. Retrieved from https://openknowledge.worldbank.org/bitstream/handle/10986/33696/148198.pdf

Schwartz, A. C. (2012). Remedial education programs to accelerate learning for all. Retrieved from http://documents1.worldbank.org/curated/en/564671468151507990/pdf/797830WPOAnaliOBox0379789B00PUBLIC0.pdf adresinden erişildi. 
Simonez, T. J. (2016). Remedial education programs and student success: Perceptions of faculty and administrators at HBCUs. Yayımlanmamış Doktora Tezi, Georgia Southern University, ABD.

Suna, H. E., Tanberkan, H., \& Özer, M. (2020). Changes in literacy of students in Turkey by years and school types: Performance of students in PISA applications. Journal of Measurement and Evaluation in Education and Psychology, 11(1), 76-97.

Suna, H. E., Tanberkan, H., Gür, B. S., Perc, M., \& Özer, M. (2020a). Socioeconomic status and school type as predictors of academic achievement, Journal of Economy Culture and Society, 61, 41-64.

Suna, H. E., Gür, B. S., Gelbal, S., \& Özer, M. (2020b). Fen lisesi öğrencilerinin sosyoekonomik arkaplanı ve yükseköğretime geçişteki tercihleri. Yükseköğretim Dergisi, 10(3), 356-370.

Suna, H. E., \& Özer, M. (2021a). The achievement gap between schools and relationship between achievement and socioeconomic status in Turkey. Eğitimde ve Psikolojide Ölçme ve Değerlendirme Dergisi, 12(1), 54 - 70.

Suna, H. E., \& Özer, M. (2021b). The impact of school tracking on secondary vocational education and training in Turkey. Hacettepe Üniversitesi Eğitim Fakültesi Dergisi, doi: 10.16986/HUJE.2021068158.

Wilson, S. J., Tanner-Smith, E. E., Lipsey, M. W., Steinka-Fry, K., \& Morrison, J. (2011). Dropout prevention and intervention programs: Effects on school completion and dropout among school-aged children and youth. Campbell Systematic Reviews 2011:8, The Campbell Collaboration. Retrieved from https://onlinelibrary.wiley.com/doi/epdf/10.4073/csr.2011.8 